\title{
Kepemilikan Manajerial, Proporsi Dewan Komisaris Independen, Komite Audit dan Penghindaran Pajak
}

\author{
I Dewa Agung Ayu Mega Maharani Martha ${ }^{1}$ \\ Fakultas Ekonomi dan Bisnis \\ Universitas Udayana, Indonesia
}

\author{
I Ketut Jati ${ }^{2}$ \\ Fakultas Ekonomi dan Bisnis \\ Universitas Udayana, Indonesia
}

\begin{abstract}
Surel : megamarthaa26@gmail.com
ABSTRAK

Pajak adalah sumber pendanaan penting bagi perekonomian Indonesia. Tax Avoidance adalah usaha perusahaan guna meminimalisir beban pajak perusahaan dengan mencari celah kelemahan pajak sebuah negara, jadi skema tersebut legal. Penelitian ini bertujuan mendapatkan bukti empiris korelasi kepemilikan manajerial, proporsi dewan komisaris independen, serta komite audit pada penghindaran pajak. Teori yang dipergunakan yakni Teori Keagenan. Penelitian dilaksanakan pada entitas pertambangan yang melantai di BEI pada kurun waktu 2017-2019, dengan populasi sebesar 43 entitas. Jumlah sampel yang diperoleh yakni 11 entitas dengan metode purposive sampling. Data dikumpulkan dengan observasi non partisipan. Teknik analisis data yang diterapkan ialah regresi linear berganda. Hasil temuan menyatakan proporsi dewan komisaris independen mempunyai pengaruh negatif pada penghindaran pajak. Namun, kepemilikkan manajerial serta komite audit tidak mempunyai pengaruh pada penghindaran pajak.
\end{abstract}

Kata Kunci: Kepemilikkan Manajerial; Proporsi Dewan Komisaris Independen; Komite Audit.

\section{Managerial Ownership, Proportion of Independent Commissioners, Audit Committee and Tax Avoidance}$$
\text { ABSTRACT }
$$

Taxes are an important source of funding for the Indonesian economy. Tax Avoidance is a company's effort to minimize the company's tax burden by looking for gaps in a country's tax weaknesses, so the scheme is legal. This study aims to obtain empirical evidence of the correlation of managerial ownership, the proportion of independent commissioners, and the audit committee on tax avoidance. The theory used is the Agency Theory. The research was carried out on mining entities that are on the IDX in the period 2017-2019, with a population of 43 entities. The number of samples obtained are 11 companies with purposive sampling method. Data collection is done by non-participant observation. The data analysis technique applied is multiple linear regression. The findings indicate that the proportion of independent commissioners has a negative effect on tax avoidance. However, managerial ownership and audit committee have no effect on tax avoidance.
\end{abstract}

Keywords: Managerial Ownership; The Proportion of Independent Comissioners; Audit Committee.

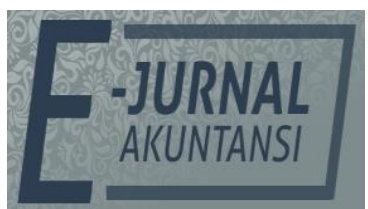

e-ISSN 2302-8556

Vol. 31 No. 9

Denpasar, September 2021 Hal. 2265-2276

DOI:

10.24843/EJA.2021.v31.i09.p09

PENGUTIPAN:

Martha, I.D.A.A.M.M., \& Jati, I.K. (2021). Kepemilikan

Manajerial, Proporsi Dewan Komisaris Independen, Komite Audit dan

Penghindaran Pajak. E-Jurnal Akuntansi, 31(9), 2265-2276

RIWAYAT ARTIKEL:

Artikel Masuk:

24 Mei 2021

Artikel Diterima: 11 Agustus 2021

Artikel dapat diakses : https://ojs.unud.ac.id/index.php/Akuntansi/index 


\section{PENDAHULUAN}

Pada penghujung tahun 2019 menurut data yang disampaikan oleh Kementerian Keuangan Republik Indonesia, dimana penerimaan perpajakan hanya sebesar Rp1.332,1 triliun atau 84,4 persen dari target APBN tahun 2019. Realisasi penerimaan pajak mengalami pertumbuhan sebesar 1,4 persen dari tahun 2018, akan tetapi realisasi tidak sesuai dengan dengan target penerimaan. Data target serta realisasi penerimaan pajak kurun waktu 2017-2019 tersaji pada Tabel 1.

Tabel 1. Target dan Realisasi Penerima Pajak Tahun 2017-2019 (Dalam Triliun Rupiah)

\begin{tabular}{cccc}
\hline & 2017 & 2018 & 2019 \\
\hline Target & 1.283 & 1.424 & $1.577,6$ \\
Realisasi & 1.147 & $1.315,9$ & $1.332,1$ \\
Shortfall & 136 & 108 & 245,5 \\
Capaian & $89,4 \%$ & $92 \%$ & $84,4 \%$ \\
\hline
\end{tabular}

Sumber: Data Penelitian, 2020

Pemerintah memberi fasilitas dibidang perpajakan seperti penurunan tarif pajak badan yang ditetapkan pada UU No. 36 Tahun 2008 pasal 17 ayat (1) huruf b, dimana tarif pajak badan dalam negeri serta bentuk usaha tetap yaitu 28 persen. Selanjutnya, tarif ini mengalami revisi hingga menjadi 25 persen yang mulai berlaku sejak tahun 2010. Tak hanya melalui penurunan tarif pajak, pemerintah juga turut menyederhanakan perhitungan pajaknya dan tercantum pada PP No. 46 Tahun 2013 yang isinya, penyederhanaan perhitungan pajak yang mana badan yang mempunyai peredaran bruto kurang dari Rp 4,8 miliar dalam satu tahun, diterapkan tarif 1 persen, tidak hanya itu, pemerintah juga menerapkan sistem pengampunan pajak atau tax amnesty. Meskipun pemerintah telah menerapkan berbagai sistem agar target realisasi penerimaan pajak negara tercapai, masih banyak wajib pajak yang menerapkan strategi pajak yang agresif agar dapat menurunkan biaya pajak yang harus dibayarkan seperti salah satunya yaitu praktik penghindaran pajak. Namun tidak semua perusahaan melaksanakan usaha penghindaran pajak karena mereka menganggap tax avoidance dapat menimbulkan biaya perpajakan yang lebih besar (Charisma \& Dwimulyani, 2019).

Ada beberapa penyebab sebuah perusahaan melakukan pembayaran pajak, salah satunya ialah tata kelola suatu perusahaan atau Corporate Governance. Tata kelola perusahaan dapat dilihat dari berbagai segi, seperti kepemilikkan manajerial, proporsi dewan komisari independen, dan komite audit. Kepemilikkan manajerial adalah kepemilikan oleh pihak internal perusahaan. Meningkatnya kepemilikan manajerial pada sebuah perusahaan berdampak pada menurunnya masalah keagenan yang disebabkan oleh pihak manajerial berlaku sebagai pihak agen maupun prinsipal. Dimana, kepemilikan manajerial dapat menekan tindakan keagenan yang dapat menimbulkan konflik kepentingan dan berdampak dalam memberi motivasi terhadap kinerja manajemen dalam meningkatkan laba. Selanjutnya, komisaris independen berperan sebagai mediator manajamen entitas dengan pemilik entitas ketika mengambil kebijakan guna mencegah terjadinya pelanggaran hukum, termasuk dalam menentukan kiat-kiat pembayaran pajak. Dikarenakan komisaris independen mempunyai kewajiban atas kepentingan dari para pemegang saham, jadi pihak komisaris 
independen sangat mengusahakan untuk taat dalam membayar pajak serta menghindari tindakan tax avoidance. Peran komite audit juga berpengaruh pada tata kelola perusahaan, dimana keberadaan komite audit turut serta dalam mendukung kinerja dewan komisaris, dimana komite audit mempunyai kewenangan dalam menghindari perbuatan yang tidak sesuai aturan yang hubungannya dengan laporan keuangan suatu perusahaan salah satunya tindakan penghindaran pajak.

Manajemen biasanya ingin menerima kompensasi yang lebih banyak dengan cara tidak mengungkapkan laporan keuangan yang sesungguhnya. Hal ini karena laporan keuangan adalah barometer kesuksesan manajemen. Hubungan keagenan sering menciptakan masalah antar agen dan principal, sebab terdapat pola pikir dan kepentingan yang berbeda. Prosedur yang sesuai dalam mencegah permasalahan keagenan yakni dengan adanya kepemilikan manajerial . Penelitian yang dilakukan oleh Prasetyo \& Pramuka (2018), Pramudito \& Sari (2015), Charisma \& Dwimulyani (2019) menyatakan, kepemilikan manajerial mempunyai pengaruh negatif pada tax avoidance. Atas dasar teori serta hasil penelitian oleh peneliti sebelumnya, maka dapat ditarik hipotesis sebagai berikut. $\mathrm{H}_{1}$ : Kepemilikan manajerial mempunyai pe ngaruh negatif pada penghindaran pajak.

Dewan komisaris independen dihubungkan dengan penerapan asas-asas Good Corporate Governance (GCG) pada suatu perusahaan, yang diharapkan mampu memenuhi syarat transparan, akuntabel, adil, serta bertanggungjawab, baik pada pemegang saham ataupun pada pemangku kepentingan lainnya, yakni masyarakt dan lingkungan, sehingga dewan komisaris independen dapat dijadikan sebagai penengah dalam hubungan antara principal dan agent. Penelitian oleh Diantari \& Ulupui (2016), Ariawan \& Setiawan (2017), Sandy \& Lukviarman (2015) menyatakan, proporsi komisaris independen mempunyai pengaruh negatif pada penghindaran pajak. Sesuai teori serta hasil penelitian sebelumnya, dapat ditarik hipotesis sebagai berikut.

$\mathrm{H}_{2}$ : Proporsi komisaris independen mempunyai pengaruh negatif pada penghindaran pajak.

Komite audit bertanggung jawab untuk menelaah informasi keuangan yang akan dipublikasikan ke publik, jadi komite audit perlu memeriksa informasi keuangan atau laporan keuangan yang akan dipublikasikan oleh manajemen sebelum nantinya digunakan oleh pihak-pihak tertentu seperti investor. Komite audit dari dewan komisaris independen tentunya akan berhubungan dengan pemilik perusahaan (principal) dan manajemen (agent) terkait pemeriksaan laporan keuangan atau laporan tahunan yang akan dipublikasikan agar sesuai dengan undang-undang terkait aktivitas entitas publik salah satunya undang-undang perpajakan. Penelitian Diantari \& Ulupui (2016), Asri \& Suardana (2016), Eksandy (2017), menyimpulkan, komite audit mempunyai pengaruh negatif pada penghindaran pajak. Atas dasar teori serta hasil penelitian sebelumnya, dapat ditarik hipotesis sebagai berikut.

$\mathrm{H}_{3}$ : Komite audit mempunyai pengaruh negatif pada penghindaran pajak. 


\section{METODE PENELITIAN}

Penelitian dilaksanakan di entitas pertambangan yang melantai di BEI dan mempublikasikan laporan keuangan serta laporan tahunannya (annual report), dengan membuka laman web BEI (www.idx.co.id). Data kuantitatif penelitian ini yakni beban pajak penghasilan, laba sebelum pajak, total saham manajer dan total saham beredar pada laporan keuangan entitas pertambangan yang melantai di Bursa Efek Indonesia periode 2017-2019. Data kualitatif penelitian ini adalah total dewan komisaris independen, jumlah anggota komisaris, serta jumlah komite audit yang tercatat dalam laporan tahunan (annual report) dari perusahaan pertambangan yang terdaftar di Bursa Efek Indonesia periode 2017-2019. Obyek pada penelitian ini tiada lain penghindaran pajak yang direpresentasikan dengan nilai Effective Tax Rates (ETR), Kepemilikan Manajerial, Proporsi Dewan Komisaris Independen, dan Komite Audit, entitas pertambangan dalam hal ini yang melantai di Bursa Efek Indonesia tahun 2017-2019. Dimana rasio ETR diukur dengan perhitungan sebagai berikut.

ETR $=\frac{\text { Beban Pajak Penghasilan }}{\text { Laba Sebelum Pajak }}$

Kepemilikan manajerial dalam penelitian ini ditujukan untuk mengetahui seberapa besar kepemilikan saham milik pihak internal sebuah entitas. Adapun rumus yang dapat digunakan untuk mengukur kepemilikan manajerial adalah sebagai berikut.

$\mathrm{KM}=\frac{\text { TOTAL SAHAM MANAJER }}{\text { TOTAL SAHAM BEREDAR }}$

Proporsi dewan komisaris independen memiliki tujuan untuk mengetahui seberapa besar pengaruh dewan komisaris independen yang tidak termasuk anggota manajemen ataupun pemegang saham mayoritas terhadap tata kelola perusahaan khususnya menegnai tax avoidance. Proporsi komisaris independen dirumuskan sebagai berikut (Prasetyo \& Pramuka, 2018).

PKI $=\frac{\text { TOTAL DEWAN KOMISARIS INDEPENDEN }}{\text { TOTAL ANGGOTA KOMISARIS }} \times 100 \%$.

Komite audit ialah tambahan komite yang dibuat dewan komisaris guna memudahkan dalam melakukan pengawasan manajemen sebuah entitas pada penyusunan laporan keuangan dan pemberian wawasan terkait permasalahan kebijakan keuangan, akuntansi serta pengendalian internal sebuah entitas. Komite audit keberadaannya dinilai dengan jumlah komite audit pada suatu (Asri \& Suardana, 2016)

Komite Audit = Jumlah Komite Audit yang Terdapat dalam suatu perusahaan..(4)

Populasi penelitian ini yakni seluruh entitas pertambangan yang melantai di Bursa Efek Indonesia perode 2017-2019. Sampel penelitian ini yakni beberapa entitas pertambangan yang melantai di Bursa Efek Indonesia pada kurun waktu 2017-2019 dimana telah dipilih menggunakan teknik nonprobability sampling. Bagian dari teknik nonprobability sampling yang dipakai ialah purposive sampling. Persyaratan sampel pada penelitian ini yakni entitas pertambangan yang melantai di Bursa Efek Indonesia kurun waktu 2017-2019 serta tidak pernah didelisting pada kurun waktu tersebut, entitas menyajikan laporan tahunan dan laporan keuangan kurun waktu 2017-2019 secara berkesinambungan, perusahan tidak mengalami kerugian pada kurun waktu tersebut. Hal tersebut menjadi penting karena dapat menyebabkan ETR menjadi negatif, jadi akan mempersulit 
perhitungan, dan entitas pertambangan yang menyajikan data secara lengkap mengenai variabel-variabel yang dipergunakan. Teknik analisis data mempergunakan regresi linear berganda, dimana sebelumnya model regresi wajib lolos uji asumsi klasik. Adapun model regresi dalam penelitian ini adalah.

$$
\begin{aligned}
& Y=\alpha+\beta_{1} X_{1}+\beta_{2} X_{2}+\beta_{3} X_{3}+\varepsilon \\
& \text { Keterangan : } \\
& \mathrm{Y}=\text { Penghindaran Pajak } \\
& \mathrm{X}_{1} \quad=\text { Kepemilikan manajerial } \\
& \mathrm{X}_{2}=\text { Proporsi komisaris independen } \\
& \mathrm{X}_{3} \quad=\text { Komite audit } \\
& \text { a } \quad \text { Konstanta } \\
& \beta_{1}-\beta_{3}=\text { Koefisien regresi } \\
& \varepsilon \quad=\text { Variabel pengganggu }
\end{aligned}
$$

\section{HASIL DAN PEMBAHASAN}

Hasil statistik deskriptif memberikan gambaran atau deskripsi suatu data yang dilihat dari nilai terendah, tertinggi, mean, serta standar deviasi. Hasil statistik deskriptif disajikan pada Tabel 2, berikut.

Tabel 2. Hasil Uji Statistik Deskriptif

\begin{tabular}{lccccc}
\hline & $\mathrm{N}$ & Minimum & Maximum & Mean & Std. Deviation \\
\hline $\begin{array}{l}\text { Penghindaran } \\
\text { Pajak (ETR) }\end{array}$ & 33 & 0,072 & 0,908 & 0,337 & 0,169 \\
$\begin{array}{l}\text { Kepemilikkan } \\
\text { Manajerial (KM) }\end{array}$ & 33 & 0,000 & 0,282 & 0,045 & 0,085 \\
$\begin{array}{l}\text { Proporsi Dewan } \\
\text { Komisaris }\end{array}$ & 33 & 0,250 & 0,500 & 0,382 & 0,071 \\
$\begin{array}{l}\text { Independen } \\
\text { (PDKI) }\end{array}$ & & & & & \\
$\begin{array}{l}\text { Komite Audit } \\
\text { (KA) }\end{array}$ & 33 & 3 & 4 & 3,18 & 0,392 \\
Valid N (listwise) & 33 & & & & \\
\hline
\end{tabular}

Sumber: Data Penelitian, 2020

Menurut hasil uji statistik deskriptif pada Tabel 2, variabel penghindaran pajak yang direpresentasikan dengan ETR (Effective Tax Rate) pada entitas pertambangan yang melantai di BEI menunjukkan bahwa dari 33 sampel pengamatan, nilai terendah penghindaran pajak sebesar 0,072 serta nilai tertinggi penghindaran pajak sebesar 0,908. Nilai deviasi standar variabel penghindaran pajak sebesar 0,169 berarti standar penyimpangan data terhadap nilai mean sebesar 0,169 .

Kepemilikan manajerial yang diproksikan dengan KM pada Tabel 2, dari 33 sampel pengamatan diperoleh nilai terendah kepemilikan manajerial sejumlah 0,000 serta nilai tertinggi kepemilikkan manajerial yakni 0,282. Nilai deviasi standar variabel kepemilikkan manajerial sebesar 0,085 berarti standar penyimpangan data terhadap nilai mean sebesar 0,085.

Proporsi dewan komisaris independen yang dirpoksikan dengan PDKI pada Tabel 2, dari 33 sampel pengamatan diperoleh nilai terendah proporsi dewan komisaris independen yakni 0,250 . Sementara itu, nilai tertinggi proporsi dewan komisaris independen yakni 0,500. Nilai deviasi standar variabel proporsi dewan 
komisaris independen adalah 0,071 berarti standar penyimpangan data pada nilai rata-ratanya sebesar 0,071 .

Komite audit yang diproksikan dengan KA pada Tabel 2, dari 33 sampel pengamatan diperoleh nilai terendah komite audit adalah tiga dan nilai tertinggi komite audit adalah empat. Nilai rata-rata komite audit adalah 3,180. Nilai deviasi standar variabel komite audit adalah 0,392 berarti standar penyimpangan data terhadap nilai mean sebesar 0,392 .

Tabel 3. Hasil Uji Normalitas

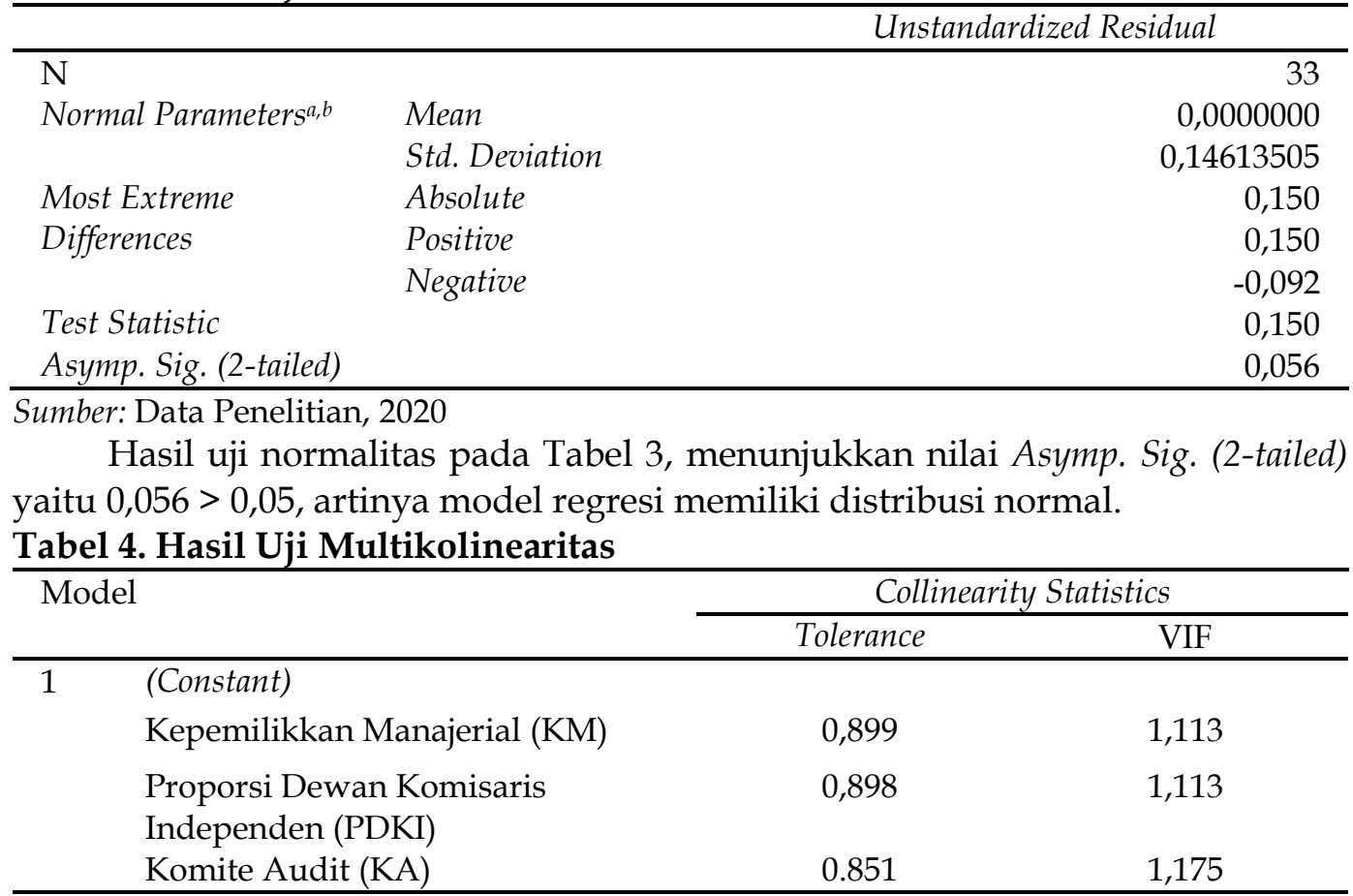

Sumber: Data Penelitian, 2020

Berdasarkan hasil uji multikolinearitas pada Tabel 4, menunjukkan bahwa variabel bebas dalam penelitian ini yaitu kepemilikan manajerial, proporsi dewan komisaris independen, serta komite audit mempunyai nilai tolerance $>0,10$ atau nilai VIF < 10, ini berarti variabel independen pada penelitian ini bebas dari gejala multikolinearitas.

Tabel 5. Hasil Uji Autokorelasi dengan menggunakan Runs Test

\begin{tabular}{lr}
\hline \multicolumn{2}{c}{ Unstandardized Residual } \\
\hline Test Valuea & -.01368 \\
Cases $<$ Test Value & 16 \\
Cases >= Test Value & 17 \\
Total Cases & 33 \\
Number of Runs & 16 \\
Z & $-0,349$ \\
Asymp. Sig. (2-tailed) & 0,727 \\
\hline
\end{tabular}

Sumber: Data Penelitian, 2020

Berdasarkan hasil uji autokorelasi menggunakan runs test pada Tabel 5, diperoleh nilai Asymp. Sig (2-tailed) sebesar 0,727 maka Asymp. Sig (2-tailed) >0,05. Nilai residual bersifat acak, artinya tidak terdapat gejala autokorelasi antar nilai residual. 
Tabel 6. Hasil Uji Heterokedastisitas

\begin{tabular}{lccc}
\hline \multicolumn{1}{c}{ Model } & Sig. & Standar & \multicolumn{1}{c}{ Keterangan } \\
\hline $\begin{array}{l}\text { Kepemilikkan } \\
\text { Manajerial (KM) }\end{array}$ & 0,591 & $>0,05$ & Tidak ada gejala heteroskedastisitas \\
$\begin{array}{l}\text { Proporsi Dewan } \\
\text { Komisaris }\end{array}$ & 0,280 & $>0,05$ & Tidak ada gejala heteroskedastisitas \\
$\begin{array}{l}\text { Independen (PDKI) } \\
\text { Komite Audit } \\
\text { (KA) }\end{array}$ & 0,584 & $>0,05$ & Tidak ada gejala heteroskedastisitas \\
\hline
\end{tabular}

Sumber: Data Penelitian, 2020

Tabel 6, menunjukkan hasil pengujian heteroskedastisidas dengan Uji RankSpearman, dimana signifikansi setiap variabel independen memiliki nilai $>0,05$ atau 5 persen artinya tidak ada gejala heteroskedastisitas.

Tabel 7. Hasil Analisis Regresi Linear Berganda

\begin{tabular}{|c|c|c|c|c|c|c|}
\hline \multicolumn{2}{|c|}{ Model } & \multicolumn{2}{|c|}{$\begin{array}{c}\text { Unstandardized } \\
\text { Coefficients }\end{array}$} & \multirow{2}{*}{$\begin{array}{c}\begin{array}{c}\text { Standardized } \\
\text { Coefficients }\end{array} \\
\text { Beta }\end{array}$} & \multirow[t]{2}{*}{$\mathrm{T}$} & \multirow[t]{2}{*}{ Sig. } \\
\hline & & $\mathrm{B}$ & Std. Error & & & \\
\hline \multirow[t]{6}{*}{ 1) } & (Constant) & 0,697 & 0,328 & & 2,128 & 0,042 \\
\hline & Kepemilikkan & - & 0,334 & $-0,186$ & $-1,096$ & 0,282 \\
\hline & Manajerial (KM) & 0,367 & & & & \\
\hline & Proporsi Dewan & - & 0,406 & $-0,463$ & $-2,735$ & 0,011 \\
\hline & $\begin{array}{l}\text { Komisaris } \\
\text { (PDKI) }\end{array}$ & 1,109 & & & & \\
\hline & $\begin{array}{l}\text { Komite Audit } \\
\text { (KA) }\end{array}$ & 0,025 & 0,075 & 0,059 & 0,338 & 0,738 \\
\hline
\end{tabular}

Sumber: Data Penelitian, 2020

Sesuai hasil pada Tabel 7, persamaan regresi linier berganda adalah sebagai berikut.

$$
\mathrm{Y}=0,679-0,367 \mathrm{KM}-1,109 \text { PDKI }+0,025 \mathrm{KA}+\varepsilon
$$

Hipotesis pertama penelitian berbunyi kepemilikkan manajerial mempunyai pengaruh negatif pada penghindaran pajak. Sesuai Tabel 7, hasil uji diperoleh nilai koefisien regresi yaitu $-0,367$, nilai signifikansi yaitu 0,282. Dimana kepemilikkan manajerial pada perusahaan pertambangan yang terdaftar di BEI periode 2017 - 2019 tidak berpengaruh pada ETR yang berarti tidak mempunyai pengaruh pada kegiatan penghindaran pajak, sehingga hipotesis ditolak. Hasil penelitian ini sesuai dengan hasil dari penelitian Mahulae et al (2016) dan Krisna (2019) yang menyatakan bahwa kepemilikkan manajerial tidak berpengar uh pada penghindaran pajak. Pihak manajerial tidak mempunyai kuasa besar guna mengambil keputusan, alhasil pihak manajerial tak mempunyai kewenangan yang besar di sebuah entitas. Oleh sebab itu, kepemilikan manajerial tidak mempunyai pengaruh pada penghindaran pajak di entitas pertambangan yang melantai di Bursa Efek Indonesia (BEI) pada kurun waktu 2017-2019.

Hipotesis kedua penelitian ini berbunyi, proporsi dewan komisaris independen mempunyai pengaruh negatif pada penghindaran pajak. Sesuai Tabel 7, diperoleh nilai koefisien regresi yaitu -1,109, nilai signifikansi yakni 0,011. Tingkat proporsi dewan komisaris independen pada entitas pertambangan yang ada di BEI kurun waktu 2017 - 2019 berpengaruh negatif pada ETR yang menentukan timbulnya aktivitas tax avoidance oleh perusahaan. Hasil penelitian 
ini sesuai dengan penelitian oleh Sandy \& Lukviarman (2015), Diantari \& Ulupui (2016), Ariawan, \& Setiawan (2017), yang menyimpulkan, proporsi komisaris independen mempunyai pengaruh negatif pada penghindaran pajak. Komisaris independen mampu melakukan pengawasan atas manajemen sebuah entitas supaya mematuhi ketentuan yang sedang berlaku, jadi mampu memperkecil kemungkinan dilaksanakannya aktivitas penghindaran pajak.

Hipotesis ketiga penelitian ini berbunyi, komite audit mempunyai pengaruh negatif pada penghindaran pajak. Sesuai Tabel 7, hasil uji diperoleh nilai koefisien regresi yakni 0,025 dan nilai signifikansi yakni 0,738. Dimana jumlah komite audit pada perusahaan pertambangan yang terdaftar di BEI periode 2017 - 2019 tidak berpengaruh pada tax avoidance (ETR), jadi hipotesis ditolak. Hasil penelitian ini mendukung hasil penelitian Damayanti \& Susanto (2016), Swingly \& Sukartha (2015), Ayu et al (2017), Vidiyanti (2017) yang menjelaskan tingkat komite audit tidak mempunyai pengaruh pada tax avoidance. Pihak lain memiliki fungsi yang lebih besar dalam mengambil keputusan dibandingkan komite audit, meskipun komite audit bersumber dari pihak eksternal. Disamping fungsinya yang tidak cukup besar, tidak adanya pengaruh antara komite audit dengan tax avoidance dapat diakibatkan pula oleh tidak mampunya komite audit independen melaksanakan tugas monitoring atas struktur pengendalian internal sebuah entitas dan juga monitoring proses evaluasi yang dilaksanakan auditor internal secara baik alhasil aktivitas penghindaran pajak oleh pihak tetentu tidak mampu dilacak oleh para komite audit.

\section{SIMPULAN}

Menurut hasil penelitian, dapat ditarik simpulan bahwa tingkat kepemilikan manajerial tidak mempunyai pengaruh pada tax avoidance, ini karena pihak manajerial tak mempunyai hak cukup besar dalam mengambil keputusan. Proporsi dewan komisaris independen berpengaruh negatif pada tax avoidance, hal ini akibat kehadiran komisaris independen pada perusahaan dapat mengawasi dengan ketat sebuah manajemen, alhasil mampu mengurangi tindakan disfungsional yang mungkin timbul, misalnya penghindaran pajak. Jumlah komite audit tidak berpengaruh pada tax avoidance, ini karena pihak lain mempunyai fungsi yang lebih besar untuk mengambil keputusan, dibandingkan dengan komite audit perusahaan meskipun komite audit adalah pihak eksternal perusahaan serta tidak mampunya komite audit independen melaksanakan pekerjaannya untuk mengawasi struktur pengendalian internal.

Bagi peneliti selanjutnya yang ingin membuktikan adanya pengaruh kepemilikkan manajerial, proporsi dewan komisaris independen, serta komite audit pada praktik penghindaran pajak diharapkan dapat menggunakan variabel lainnya yang diduga dapat memengaruhi praktik penghindaran pajak yang memproksikan good corporate governance seperti kepemilikkan institusional. Kemudian, peneliti selanjutnya juga diharapkan memperlebar jangkauan penelitian, yaitu meneliti selain entitas pertambangan, misalnya pada perusahaan perbankan, perusahaan manufaktur, dan sektor-sektor lainnya. 


\section{REFERENSI}

Ariawan, I. M. A. R., \& Setiawan, P. E. (2017). Pengaruh Dewan Komisaris Independen, Kepemilikan Institusional, Profitabilitas Dan Leverge Terhadap Tax Avoidance. E-Jurnal Akuntansi, 18(3), 1831-1859.

Armstrong, C. S., Blouin, J. L., Jagolinzer, A. D., \& Larcker, D. F. (2015). Corporate governance, incentives, and tax avoidance. Journal of Accounting and Economics, 60(1), 1-17.

Asri, I. A. T. Y., \& Suardana, K. A. (2016). Pengaruh Proporsi Komisaris Independen, Komite Audit, Preferensi Risiko Eksekutif Dan Ukuran Perusahaan Pada Penghindaran Pajak. E-Jurnal Akuntansi, 16(1), 72-100.

Astuti, T. P., \& Aryani, Y. A. (2016). Tren Penghindaran Pajak Perusahaan Manufaktur di Indonesia yang Terdaftar di BEI Tahun 2001-2014. Jurnal Akuntansi, 20(3), 375-388.

Ayu, F., Mukhzarudfa, M., \& Asep, M. (2017). Pengaruh Kepemilikan Institusional, Dewan Komisaris Independen, Kualitas Audit, Komite Audit, Karakter Eksekutif, Dan Leverage Terhadap Tax Avoidance (Studi Empiris Pada Perusahaan Manufaktur di Bursa Efek Indonesia dengan Tahun Pengamatan 2010-2014). Jurnal Akuntansi \& Keuangan Unja, 2(2), 12-21., 17 (59).

Bachtiar, M. D., \& Zulaikha, Z. (2015). Pengaruh Struktur Kepemilikan, Ukuran Perusahaan, Dan Capital Intensity Terhadap Effective Tax Rate (ETR)(Studi Empiris pada Perusahaan Manufaktur yang Terdaftar di Bursa Efek Indonesia Periode 2011-2013) (Doctoral dissertation, Fakultas Ekonomika dan Bisnis).

Bayar, O., Huseynov, F., \& Sardarli, S. (2018). Corporate governance, Tax avoidance, and financial constraints. Financial Management, 47(3), 651-677.

Beer, S., De Mooij, R., \& Liu, L. (2018). International corporate tax avoidance: A review of the channels, magnitudes, and blind spots. Journal of Economic Surveys.

Budiarti, S. S. D. (2017). Pengaruh Good Corporate Governance Terhadap Tax Avoidance (Studi Empiris pada Sektor Perbankan yang Terdaftar di BEI Periode 2014-2016) (Doctoral dissertation, Universitas Bakrie).

Cahyono, D. D., Andini, R., \& Raharjo, K. (2016). Pengaruh komite audit, kepemilikan institusional, dewan komisaris, ukuran perusahaan (Size), leverage (DER) dan profitabilitas (ROA) terhadap tindakan penghindaran pajak (tax avoidance) pada perusahaan perbankan yang listing BEI periode tahun 2011-2013. Journal Of Accounting, 2(2)

Campbell, K., \& Helleloid, D. (2016). Starbucks: Social responsibility and tax avoidance. Journal of Accounting Education, 37, 38-60.

Chan, K. H., Mo, P. L. L., \& Tang, T. (2016). Tax avoidance and tunneling: Empirical analysis from an agency perspective. Journal of International Accounting Research, 15(3), 49-66.

Charisma, R. B., \& Dwimulyani, S. (2019). Pengaruh Struktur Kepemilikan Terhadap Tindakan Penghindaran Pajak Dengan Kualitas Audit Sebagai Variabel Moderating. Prosiding Seminar Nasional Pakar, 2, 1-10.

Damayanti, F., \& Susanto, T. (2016). Pengaruh Komite Audit, Kualitas Audit, Kepemilikan Institusional, Risiko Perusahaan Dan Return on Assets 
Terhadap Tax Avoidance. Esensi, 5(2), 187-206. https://doi.org/10.15408/ess.v5i2.2341

Dewi, G. A. P., \& Sari, M. M. R. (2015). Pengaruh insentif eksekutif, corporate risk dan corporate governance pada tax avoidance. E-Jurnal Akuntansi, 13(1), 5067.

Diantari, P. R., \& Ulupui, I. A. (2016). Pengaruh Komite Audit, Proporsi Komisaris Independen, Dan Proporsi Kepemilikan Institusional Terhadap Tax Avoidance. E-Jurnal Akuntansi, 16(1), 702-732.

Eisenhardt, K. M. (1989). Agency theory: An assessment and review. Academy of management review, 14(1), 57-74.

Friana, H. (2019). DJP Dalami Dugaan Penghindaran Pajak PT Adaro Energy . tirto.id. Diakses pada, 10 September 2020, website: https://tirto.id/djpdalami-dugaan-penghindaran-pajak-pt-adaro-energy-edKk

Hanlon, M., \& Heitzman, S. (2010). A Review of Tax Research. Journal of Accounting and Economics, 50(2), 127-178.

Jensen, M. C., \& Meckling, W. H. (1976). Theory of the firm: Managerial behavior, agency costs and ownership structure. Journal of financial economics, 3(4), 305360.

Julita. S, L. (2020). Hmm.. Sudah 11 Tahun, RI Tak Mampu Capai Target Pajak . CNBC Indonesia. Diakses pada, 10 September 2020, website: https://www.cnbcindonesia.com/news/20200108133413-4-128546/hmmsudah-11-tahun-ri-tak-mampu-capai-target-pajak

Kementerian Keuangan Republik Indonesia. (2018). Pendapatan Negara. APBN KITA (Kinerja dan Fakta): Edisi Januari 2018

Kementerian Keuangan Republik Indonesia. (2019). Pendapatan Pajak. APBN KITA (Kinerja dan Fakta): Edisi Januari 2019

Kementerian Keuangan Republik Indonesia. (2020). Penerimaan Pajak. APBN KITA (Kinerja dan Fakta): Edisi Januari 2020

Krisna, A. M. (2019). Pengaruh Kepemilikan Institusional dan Kepemilikan Manajerial pada Tax Avoidance dengan Kualitas Audit sebagai Variabel Pemoderasi. Wacana Ekonomi (Jurnal Ekonomi, Bisnis dan Akuntansi), 18(2), 8291.

Lanis, R., \& Richardson, G. (2012). Corporate social responsibility and tax aggressiveness: An empirical analysis. Journal of Accounting and Public Policy, 31(1), 86-108.

Mahathir, M. (2019). Pengaruh Transfer Pricing Terhadap Tax Avoidance (Studi Kasus Pada Perusahaan Sektor Manufaktur periode 2016-2017) (Doctoral dissertation, Program Studi Akuntansi S1 Fakultas Ekonomi-Bisnis Universitas Widyatama).

Maharani, I. G. A. C., \& Suardana, K. A. (2014). Pengaruh corporate governance, profitabilitas dan karakteristik eksekutif pada tax avoidance perusahaan manufaktur. E-Jurnal Akuntansi Universitas Udayana, 9(2), 525-539.

Mashayekhi, B., \& Alipanah, S. (2015). The influence corporate governance on relationship between tax avoidance and firm's value.

Mahulae, E. E., Pratomo, D., \& Nurbaiti, A. (2016). Pengaruh Kepemilikan Institusional, Kepemilikan Manajerial Dan Komite Audit Terhadap Tax Avoidance (studi Pada Perusahaan Otomotif Yang Terdaftar Di Bursa Efek 
Indonesia Tahun 2010-2014). eProceedings of Management, 3(2).

Minnick, K., \& Noga, T. (2010). Do corporate governance characteristics influence tax management?. Journal of corporate finance, 16(5), 703-718.

Oktamawati, M. (2019). Pengaruh karakter eksekutif, komite audit, ukuran perusahaan, leverage, pertumbuhan penjualan, dan profitabilitas terhadap tax avoidance. Jurnal Akuntansi Bisnis, 15(1), 23-40..

Partha, I. G. A., \& Noviari, N. (2016). Pengaruh Penghindaran Pajak Jangka Panjang pada Nilai Perusahaan dengan Transparansi Informasi sebagai Variabel Pemoderasi. E-Jurnal Akuntansi, 14(3), 2336-2362.

Pradipta, D. H. (2015). Pengaruh Corporate Social Responsibility (CSR), Profitabilitas, Leverage, dan Komisaris Independen Terhadap Praktik Penghindaran Pajak. Universitas Gadjah Mada.

Pramudito, B. W., \& Sari, M. M. R. (2015). Pengaruh Konservatisme Akuntansi, Kepemilikan Manajerial dan Ukuran Dewan Komisaris Terhadap Tax Avoidance. E-Jurnal Akuntansi Universitas Udayana, 13(3), 705-722.

Prasetyo, I., \& Pramuka, B. A. (2018). Pengaruh Kepemilikan Institusional, Kepemilikan Manajerial dan Proporsi Dewan Komisaris Independen terhadap Tax avoidance. Jurnal Ekonomi, Bisnis, dan Akuntansi, 20(2).

Prima, B. (2019). Tax Justice laporkan Bentoel lakukan penghindaran pajak, Indonesia rugi US\$ 14 juta . kontan.co.id. Diakses pada, 10 September 2020, website: https://amp.kontan.co.id/news/tax-justice-laporkan-bentoellakukan-penghindaran-pajak-indonesia-rugi-rp-14-juta

Ratih, I., Ayu, D., Damayanthi, I., \& Eka, G. A. (2016). Kepemilikan Manajerial Dan Profitabilitas Pada Nilai Perusahaan Dengan Pengungkapan Tanggungjawab Sosial Sebagai Variabel Pemoderasi. E-Jurnal Akuntansi Universitas Udayana, 14(2), 1510-1538.

Richardson, G., \& Lanis, R. (2007). Determinants of Variability in Corporate Effective Tax Rate and Tax Reform: Evidence from Australia. Journal of Accounting and Public Policy, 26(6), 689-704. https:// doi.org/10.1016/J.JACCPUBPOL.2007.10.003

Rodriguez, E., \& Arias, A. (2012). Do Business Characteristics Determine an Effective Tax Rate? The Chinese Economy, 45(6), 60-83.

Sandy, S., \& Lukviarman, N. (2015). Pengaruh corporate governance terhadap tax avoidance: Studi empiris pada perusahaan manufaktur. Jurnal Akuntansi dan Auditing Indonesia, 19(2), 85-98.

Setianti, P. (2019). Pengaruh Profitabilitas, Leverage, Umur Perusahaan, Intensitas Modal Dan Kepemilikan Manajerial Terhadap Penghindaran Pajak (Doctoral dissertation, STIE Perbanas Surabaya).

Siregar, R., \& Widyawati, D. (2016). Pengaruh karakteristik perusahaan terhadap penghindaran pajak pada perusahaan manufaktur di BEI. Jurnal Ilmu dan Riset Akuntansi (JIRA), 5(2).

Swingly, C., \& Sukartha, I. M. (2015). Pengaruh karakter eksekutif, komite audit, ukuran perusahaan, leverage dan sales growth pada tax avoidance. E-Jurnal Akuntansi Universitas Udayana, 10(1), 47-62.

Ulupui, P. R. (2016). Pengaruh komite audit, proporsi komisaris independen, dan proporsi kepemilikan institusional terhadap tax avoidance. Jurnal Akuntansi Universitas Udayana, 16(1), 702-732. 
Vidiyanti, E. (2017). Pengaruh komite audit, kualitas audit, kepemilikan institusional, return on assets, dan leverage terhadap tax avoidance (Doctoral dissertation, STIE Perbanas Surabaya).

Watson, L. (2015). Corporate social responsibility, tax avoidance, and earnings performance. The Journal of the American Taxation Association, 37(2), 1-21.

Wijayanti, Y. C., \& Merkusiwati, N. K. L. A. (2017). Pengaruh proporsi komisaris independen, kepemilikan institusional, leverage, dan ukuran perusahaan pada penghindaran pajak. E-Jurnal Akuntansi Universitas Udayana, 20(1), 699728.

Xynas, L. (2010). Tax Planning, Avoidance and Evasion in Australia 1970-2010: The Regulatory Responses and Taxpayer Compliance. Revenue Law Journal, 20(1). 